\title{
Supernumerary nostril
}

INSERM

\section{Source}

INSERM. (1999). Orphanet: an online rare disease and orphan drug data base.

Supernumerary nostril. ORPHA:141096

Supernumerary nostril is an extremely rare congenital malformation characterized by the presence of one or more accessory nostrils, with or without accessory cartilage, located medially, above, below or laterally to the other nostrils. Unlike in polyrhinia (see this term) there is no duplication of the nasal septum/cavity. Supernumerary nostril is often associated with other congenital malformations usually of face. 